\title{
Uncertain Climate: An Investigation into Public Scepticism about Anthropogenic Climate Change
}

\author{
Wouter Poortinga ${ }^{12 *}$, Alexa Spence ${ }^{3}$, Lorraine Whitmarsh ${ }^{2}$, Stuart Capstick ${ }^{2}$, \\ Nick F. Pidgeon ${ }^{2}$
}

${ }^{1}$ Welsh School of Architecture, Cardiff University, Bute Building, King Edward VII Avenue, Cardiff, CF10 3NB, Wales, UK

${ }^{2}$ School of Psychology, Cardiff University, Tower Building, Park Place, Cardiff, CF10 3AT, Wales, UK

${ }^{3}$ Horizon Digital Economy Research, School of Psychology, University of Nottingham, Sir Colin Campbell Building, University of Nottingham Innovation Park, Triumph Road, Nottingham, NG7 2TU, England, UK

${ }^{*}$ Corresponding author

Welsh School of Architecture, Cardiff University, Bute Building, King Edward VII Avenue, Cardiff, CF10 3NB, Wales, UK; Tel: +44(0)29 2087 4755; Fax: +44(0)20 2097 4623; E-mail: PoortingaW@cardiff.ac.uk

\section{Acknowledgements}

This research was jointly funded by the UK Economic and Social Research Council (grant RES-062-23-113) and the Leverhulme Trust (F/00 407/AG).

This is a pre-copy-editing, author-produced PDF of an article accepted for publication in Global Environmental Change: Human and Policy Dimensions following peer review. The definitive publisher-authenticated version is available online at: http://dx.doi.org/10.1016/j.gloenvcha.2011.03.001 


\begin{abstract}
This study presents a detailed investigation of public scepticism about anthropogenic climate change in Britain using the trend, attribution, and impact scepticism framework of Rahmstorf (2004). The study found that climate scepticism is currently not widespread in Britain. Although uncertainty and scepticism about the potential impacts of climate change were fairly common, both trend and attribution scepticism were far less prevalent. It further showed that the different types of scepticism are strongly interrelated. Although this may suggest that the general public does not clearly distinguish between the different aspects of the climate debate, there is a clear gradation in prevalence along the Rahmstorf typology. Climate scepticism appeared particularly common among older individuals from lower socio-economic backgrounds who are politically conservative and hold traditional values; while less common among younger individuals from higher socioeconomic backgrounds who hold self-transcendence and environmental values. The finding that climate scepticism is rooted in people's core values and worldviews may imply coherent and encompassing sceptical outlook on climate change. However, the results that attitudinal certainty is mainly concentrated in non-sceptical groups suggest that climate sceptical views are not held very firmly. The implications of the findings for climate change communication and engagement are discussed.
\end{abstract}




\section{Introduction}

\subsection{Background}

Climate change is arguably one of the greatest challenges the world is facing in the 21 st century. The threats posed by climate change have set the international community the almost impossible dilemma of severely limiting the emissions of greenhouse gases or to face the considerable risks associated with global temperature rises. Many have argued that the targets in greenhouse gas reductions as agreed under the Kyoto protocol are unlikely to be sufficient to avoid dangerous climate change. The UK Government has therefore set itself the ambitious longerterm domestic target of $80 \%$ reduction in all greenhouse gases by 2050 in the legally binding Climate Change Act (Defra, 2008). Meeting this target will require major shifts towards low-carbon energy production as well as significant reductions in the demand for energy.

Public perceptions and attitudes are critically important to both the supply and the demand side of the transition to a low-carbon economy. On the supply side, public acceptance of new and innovative energy facilities such as power stations and new grid infrastructure will play a key role. We know from a range of past casestudies that community opposition can lead to delays or even cancellation of plans and construction (Boholm \& Löfstedt, 2004; Toke, 2005). In particular in the UK there has been frequent environmental controversy and at times strong public opposition across a number of renewable energy developments, including onshore and offshore wind energy (Devine-Wright, 2005), biomass energy (Upreti, 2004), and tidal power (SDC, 2008). Other low-carbon infrastructure developments such as carbon capture and storage (Shackley et al., 2005) and the proposed renewal of UK nuclear power sector (Pidgeon et al., 2008) are also likely to bring public controversy. Indeed, the UK government sees the reluctance of the public to accept new energy developments in their community as one of the main challenges to the transition to a low carbon economy (DTI, 2003). On the demand side, perceptions of the need to take mitigating action against climate change, and of the ability to act on this, can be key precursors to personal behaviour change and compliance with wider policies aimed to motivate such changes (Spence \& Pidgeon, 2009; American Psychological Association, 2010). 
Previous research has shown that awareness and self-reported knowledge of climate change has been rising steadily over the last two decades (Defra, 2002; Defra, 2007; Upham et al., 2009), with awareness of the terms 'climate change' and 'global warming' being near universal in the UK since the early 2000s (Lorenzoni et al., 2006; Whitmarsh, 2009; Whitmarsh et al., 2011). A survey conducted in 2005 found that an overwhelming majority of the British public thought that the world's climate is changing and that they consider this as one of the most pressing environmental threats (Poortinga et al., 2006). However, recent research suggests that scepticism and uncertainty about climate change has increased in both Europe and the US in the last couple of years (Eurobarometer, 2009; Department for Transport, 2010; Leiserowitz et al., 2010a); a development that may have been bolstered by the controversies surrounding leaked emails from scientists working at the Climate Research Unit at the University of East Anglia and errors made in glacial melting forecasts in the Fourth Assessment Report of the Intergovernmental Panel on Climate Change (IPCC; Berkhout, 2010), as well as perhaps the unusually harsh European winter of 2009-2010 (cf. Joireman et al, 2010). It is important to have a detailed understanding of the extent and the reasons why people hold climate sceptical views, as public scepticism and uncertainty about the existence of anthropogenic climate change may become a major barrier to the development of a more sustainable society. It will be a difficult task to convince the public to make sacrifices in terms of their lifestyle and to support renewable energy developments in their community if they do not believe the climate is changing or will have a real impact on their lives.

\subsection{Public Scepticism and Uncertainty about Climate Change}

When exploring sceptical beliefs among the general public, it has to be noted that scepticism is an imprecise term that has multiple meanings given the complex multi-faceted nature of the climate debate. Rahmstorf (2004) makes a useful distinction between trend sceptics, who deny there is such a thing as an upward trend in global temperatures, attribution sceptics, who accept that the world's climate may be changing but do not think that it is caused by human activity, and impact sceptics, who agree that the world's climate is changing as a result of human activity but do not think it will lead to substantial detrimental impacts. Furthermore, differing terms, such as scepticism, cynicism, denialism, uncertainty and ambivalence, which 
are all key characteristics of public responses to the current climate change debate, are often used interchangeably. For example, Dunlap and McCright (2010) use the term 'denial' in the same fashion as Rahmstorf uses 'scepticism' to describe disbelief in the existence, anthropogenic nature, or seriousness of climate change. Within the literature a lively debate has emerged as to whether 'unconvinced camps' should be called 'climate deniers', 'sceptics', or 'contrarians' (O’Neill \& Boykoff, 2010; Anderegg et al., 2010a;b), all of which seem to refer to a "small coterie of individuals" who are "waiting to pounce on any scientific uncertainty" (Nature editorial, 2010), whose views and expertise are incongruent with mainstream climate science consensus (Anderegg \& Harold, 2009), or who vocally challenge what they see as a false consensus of mainstream climate science through critical attacks on climate science and eminent climate scientists (McCright, 2007).

In terms of public scepticism about climate change, it is important to distinguish between different attitudinal terms such as scepticism, uncertainty, and ambivalence. Whereas the concept of scepticism refers to strongly held disbeliefs in or a rejection of the tenets of mainstream climate science, uncertainty refers to a lower subjective sense of conviction or validity as to whether climate change 'really' exists, is caused by human activity, and/or will have major impacts (cf. Petty \& Krosnick, 1995). People who express attitudinal uncertainty should therefore not be confused with those who have more active sceptical disbeliefs. Indeed, research by Whitmarsh (in press) suggests that whereas an outright rejection of the notion of anthropogenic climate change is not widespread, the proportion of the public who express some degree of uncertainty about climate change is far higher. Attitudinal ambivalence is in the social psychology literature often defined as the degree to which an attitude object is evaluated positively and negatively at the same time (Thompson et al., 1995; Jonas et al., 2000), although in many cases it is used to describe any contradictory 'evaluations' someone holds on a particular issue (cf. Breckler, 1994). In other words, people who are ambivalent about climate change possess feelings, attitudes, or beliefs that are in tension with one another (Carolan, 2010). It is, however, difficult to clearly distinguish between the different attitudinal terms in the way they are used by the general public to describe their own personal views, as well as in the way they are measured in attitudinal research. For example, Poortinga and Pidgeon (2006) have shown that measures of attitudinal ambivalence and uncertainty may be compounded into a single dimension. This suggests that 
certain 'direct' ambivalence items (e.g. "I have mixed feelings about [...]") may be measuring the same underlying construct as measures of uncertainty

All types of Rahmstorf's climate scepticism, as well as uncertainty and ambivalence, can be found among the general public in the UK and beyond. Although straightforward trend scepticism does not appear to be too widespread, many express some level of uncertainty about whether climate change is really happening (Leiserowitz et al., 2010a; Whitmarsh, in press), experience some degree of ambivalence or mixed feelings (Poortinga et al., 2006), or feel they need more information to form a clear opinion about it (Whitmarsh, 2009). Also, there is some recent evidence that at least in the US the increase in trend scepticism has been levelling off and may indicate a return to higher levels of concern about the existence of climate change (Leiserowitz et al., 2010b).

Attribution scepticism appears to be more common among the British public than trend scepticism. However, while a clear majority in the UK still believes that climate change is at least partly caused by human activity (Whitmarsh et al., 2011), there has long been a substantial minority who have been sceptical about the existence of anthropogenic climate change (e.g. Lorenzoni et al., 2006; Downing \& Ballantyne, 2007). A recent Eurobarometer (2009) poll indicated that a majority (55\%) of the European public disagreed that emissions of carbon dioxide have only a marginal impact on climate change; but also that a fairly substantial $30 \%$ agreed that it was the case. In the UK, the percentage who agreed with this statement was even higher at $44 \%$. Within the US, about one in three believe that global warming is caused mostly by natural changes in the environment while only about half think it is mostly caused by human activity (Leiserowitz et al., 2010a;b).

Finally, with regard to scepticism about the impacts of climate change, the low ranking of climate change as a concern reflects a widespread perception amongst the public that the issue is a spatially and temporally remote risk (Weber, 2010). Whilst the impacts of climate change are generally considered socially relevant, most individuals do not feel it poses a prominent personal threat (e.g. Bord et al., 2000; Lowe et al., 2006). One English survey conducted in 2003 found that less than half of the respondents thought that they will be personally affected by climate change (Whitmarsh, 2009). The recent Eurobarometer (2009) poll indicated that impact scepticism is higher in the UK than in most other countries, although not as high as in the US (Leiserowitz, 2005; Leiserowitz et al., 2010a;b). The poll found that in the 
UK $40 \%$ agree that "the seriousness of climate change has been exaggerated", compared to $27 \%$ across Europe. In a representative poll in the US, more than half of the respondents thought that global warming will not, or will barely, harm themselves, their family, or their community (Leiserowitz et al., 2010a;b). Although many people express mixed feelings about climate change, there is little evidence for ambivalence about the impacts of climate change. Pidgeon et al. (2008) found a consistently negative set of responses, with very few people seeing it as holding benefits and most seeing it as posing risks for people in Britain.

The extent attitudinal uncertainty and scepticism about the existence, anthropogenic nature, and impacts of climate change seems in part to stem from doubts about the scientific consensus on climate change. This doubt expressed by the general public may partly be a product of the media presentation of climate change as controversial and uncertain, and the human causes of climate change not being self-evident (e.g. Antilla 2005; Malka et al., 2009). A small but well-organised counter-movement that has produced the majority of the sceptical literature (Jacques et al., 2008) may have given the impression that that there is considerable disagreement among scientists, augmented by a journalistic norm for balance to present both sides of the argument even if there is widespread consensus among scientists that human activity is contributing to climate change (Boykoff \& Boykoff, 2004, Hargreaves et al., 2003). Indeed, a recent poll has shown that two out of five Americans believe that "there is a lot of disagreement among scientists about whether or not global warming is happening" (Leiserowitz et al., 2010a). In contrast to what many members of the public think, there is almost universal consensus in the scientific community about many aspects of climate change. Anderegg et al. (2010) showed that $97-98 \%$ of climate researchers support the tenets of anthropogenic climate change outlined by the IPCC, and that the relative expertise and scientific prominence of the researchers unconvinced of anthropogenic climate change are substantially below those of convinced researchers (also see Doran \& Zimmerman, 2009). Although there is legitimate uncertainty about the exact nature, scale and timing of the impacts of climate change, given the complexity of climate-human systems (Patt \& Dessai, 2005; Pidgeon \& Butler, 2009), most scientists believe that global temperatures will keep rising and are likely to cause harm to natural and human systems (Anderegg \& Harold, 2009). The public also appear to be somewhat aware of the uncertainty about the impacts of climate change, with approximately 
$40 \%$ of the British public supporting the idea that the climate system is too complex and uncertain for scientists to make useful forecasts (Downing \& Ballantyne, 2007).

Although the typology of Rahmstorf (2004) is an intuitively appealing framework for describing different forms of scepticism, it is a perspective constructed by climate scientists to describe the arguments of members of an emerging countermovement that do not accept mainstream climate science consensus, and may therefore be less appropriate to describe public views on climate change. That is, the public may not necessarily distinguish between the different components of the climate debate. Indeed, recent qualitative work suggests that scepticism about the status of climate knowledge forms a coherent view among sections of the general public (Capstick \& Pidgeon, under review). Doubts about the evidence base and methodology of climate science often relate to the veracity of scientific claims in general, the validity and importance of an anthropogenic component, as well as the severity of potential impacts. In quantitative work, Whitmarsh (in press) found that a wide range of scepticism and uncertainty items could be combined to form a reliable scepticism scale, suggesting that uncertainties about different aspects of the climate debate are closely interlinked.

Only a limited number of studies have attempted to identify the sociodemographic characteristics of people who express sceptical beliefs about climate change. A review of public attitudes to climate change suggested that older people are more likely to be sceptical (Upham et al., 2009). Yet, there is also evidence of substantial scepticism in younger age groups. In a study among 11-17 year olds, about one in ten rejected the notion of anthropogenic climate change (COI, 2008). Scepticism is also somewhat higher amongst men and car owners (Defra, 2002; 2007; Whitmarsh, 2005). Furthermore, research has highlighted the interaction between personal values and scepticism. People with more pro-environmental values are less likely to be sceptical about the seriousness of climate change; and similarly conservative political values are strongly associated with scepticism (Dunlap \& McCright, 2008a; Eurobarometer, 2009; Whitmarsh, 2009). Leiserowitz (2005) identified several distinct interpretive communities in the United States, including so-called 'naysayers' who express high levels of scepticism and perceive climate change as a very low or non-existent danger. Leiserowitz (2005) found that these climate 'naysayers' are predominantly white, male, Republican, politically conservative, holding pro-individualist, pro-hierarchist, and anti-egalitarian 
worldviews, anti-environmental attitudes, distrustful of most institutions, and highly religious. Dunlap and McCright (2008a) have shown that over the last decade climate change beliefs have largely polarised along Democratic and Republican Party lines. Growing scepticism about the news coverage of global warming has gone hand-in-hand with Republicans' declining belief that the world's climate is changing. Within the UK, Whitmarsh (in press) found that older respondents without a formal education tended to be the most sceptical about climate change. However, the strongest associations were found with political affiliation and environmental values. Those with a conservative voting intention and low environmental values tended to be the most uncertain about the reality and severity of climate change.

Although these studies have provided important information about the individuals who express doubt about climate change, a more detailed and systematic investigation of climate scepticism is needed. Previous studies have generally focused on just a single aspect of climate scepticism, without an explicit theoretical framework or specification of the type of climate scepticism that were considered. No studies have been conducted that have intentionally included indicators of trend, attribution, and impact scepticism at the same time. It is currently not clear how widespread the different types of scepticism are; whether and to what extent they are distinct in the public mind; how they are associated with related attitude aspects, such as uncertainty and ambivalence; and how they are distributed across the general British population.

\subsection{Aims of the Study}

In this study we undertake a detailed investigation of public scepticism about climate change in Britain, with a number of closely interrelated objectives. First, to explore how widespread climate sceptical beliefs are in Britain using the trend, attribution, and impact scepticism typology of Rahmstorf (2004). Second, to evaluate the robustness of the Rahmstorf (2004) typology to describe public scepticism about climate change. Here we examine whether the British public distinguish between the different types of scepticism. Previous research has suggested that the different types are closely interlinked in the public mind (e.g. Capstick \& Pidgeon, under review), and may have common ideological roots (see Objective 4). Third, to explore in what way scepticism is associated with other related attitudinal constructs. Here it is examined how strongly climate sceptical views are held (in terms of attitude 
certainty), and whether they evoke conflicting perceptions on climate change (cf. attitudinal ambivalence). The fourth and final objective of the study is to provide an in-depth profile of individuals who express sceptical views on climate change. In this study we will explore how climate sceptical views are associated with a range of socio-demographic, personal values, and voting intention variables in Britain, using a nationally representative sample. This is to show how climate sceptical beliefs are distributed across the British population and how strongly they are rooted in people's core values and worldviews (cf. Leiserowitz, 2005; Whitmarsh, in press).

\section{Method}

\subsection{Procedure and Respondents}

A nationally representative quota sample of the British population aged 15 years and older $(n=1,822)$ were interviewed face-to-face in their own homes by Ipsos-MORI between 5 January and 26th March, 2010. Computer Assisted Personal Interviews were conducted by fully trained and supervised interviewers and took 30 minutes on average to complete. Interviews were conducted at 315 sample points, which were selected randomly from a stratified sample of output areas sorted by Government Office Region and council area. Interviewers approached selected addresses within the sample points until quotas were reached for gender, age, and working status. The findings from the overall British sample are based on a core sample of 1,528, to which additional booster samples from Scotland (109) and Wales (185) were added. The data were weighted to the profile of the known British population on the basis of gender, age, working status, social grade and ethnicity. Full details of the data collection can be found in the technical report of the study (XXXX et al. 2010).

\subsection{Measures}

\subsubsection{Climate Scepticism}

A range of items was included in the survey that could be used as indicators of Climate Scepticism. Two items were used to assess Trend Scepticism. People were asked "As far as you know, do you personally think the world's climate is changing or not?", with three answer options ("yes", "no", and "don't know"); as well 
as to what extent they agree with the statement "I am uncertain that climate change is really happening" on a 5-point scale ranging from "strongly agree" to "strongly disagree". The 'don't know' responses were omitted from the analyses (6\%). Attribution Scepticism was assessed by asking "Thinking about the causes of climate change, which, if any, of the following best describes your opinion". The answer options were: "climate change is entirely caused by natural processes", "climate change is mainly caused by natural processes", "climate change is partly caused by natural processes and partly caused by human activity", "climate change is mainly caused by human activity", and "climate change is completely caused by human activity". Agreement (again, on a 5-point scale) with the statement "Most scientists agree that humans are causing climate change" was also used as indicator for attribution scepticism. Impact Scepticism was assessed by asking people to what extent they agree with the statements "The seriousness of climate change is exaggerated" and "It is uncertain what the effects of climate change will be". These items again used a 5-point scale ranging from "strongly agree" to strongly disagree".

\subsubsection{Attitudinal Certainty, Ambivalence, and Affect}

Related attitude aspects were assessed as follows. An Attitude Certainty scale (Cronbach's $\alpha=0.82$ ) was constructed using the items "I have strong opinions about climate change" and "My emotions relating to climate change are quite strong". Attitudinal Ambivalence was measured with a direct measure ("I have mixed feelings about climate change") and assessed indirectly on the basis of the perceived risks and benefits of the impacts of climate change ("There are [risks/benefits] to people in Britain from climate change"). An indirect Ambivalence Index was calculated using the equation of Thompson et al. (1995). The resulting scale ranged from -1 to 5 , with higher scores representing more conflicting risk and benefit perceptions. As previous research has shown that climate change has negative affective connotations for almost all (Leiserowitz, 2005), which may lead to cognitive-affective ambivalence among climate sceptical individuals (cf. Lavine et al., 1998), a general 'Affect' indicator was included ("On a purely emotional level, how do you personally feel about climate change") with a 5-point response scale (from "very positive" to "very negative"). 


\subsubsection{Personal Values}

Personal values were measured using the short version of the Schwarz Value Survey (SVS; Schwartz, 1992). Schwartz (1992) proposed that the ten motivationally distinct 'universal' values of Power, Achievement, Hedonism, Stimulation, SelfDirection, Universalism, Benevolence, Tradition, Conformity and Security can be organised according to the two dimensions of Conservation versus Openness to Change and Self-Transcendence versus Self-enhancement. The reliability and validity of the short (10-item) version of the SVS has been demonstrated empirically by Lindemann and Verkasalo (2005). In addition to the ten value items, four further items from the SVS were included to measure environmental values. These or comparable 'biospheric' value items have been used extensively in previous research (e.g. Stern, 2000; Poortinga et al., 2004; Slimak \& Dietz, 2006; De Groot \& Steg, 2008). Five standardised value scales were created with reasonable reliabilities (Cronbach's a): Self-enhancement (Power, Achievement, Hedonism) 0.62, Self-transcendence (Universalism, Benevolence) 0.62, Openness to Change (Stimulation, Self-Direction) 0.67, Traditional Values (Tradition, Conformity, Security) 0.75 , and Environmental Values 0.91.

\subsubsection{Socio-Demographics}

The socio-demographic variables of gender, age, and social grade were included in the analyses. Forty-eight percent of the sample was male. Five dummy variables represented the six age categories of 17-24, 25-34, 35-44, 45-54, 55-64, and 65 years and $(15 \%, 14 \%, 18 \%, 17 \%, 14 \%$, and $22 \%$, respectively). In this study we used the NRS (National Readership Survey) social grades system of socioeconomic classification, based on the occupation of the head of the household. The categories included $A B$ : upper middle class and middle class (26\%). C1: lower middle class (31\%), C2: skilled working class (21\%), and DE, working class and those at the lowest level of subsistence (23\%). Furthermore, voting intention was assessed by asking "How would you vote if there were a General Election tomorrow?". Dummy variables were used to represent Conservative (19\%), Labour (16\%), Liberal Democrats (10\%), Other (Green Party, UKIP, BNP, Scottish 
Nationalists, Welsh Nationalists, Democratic Party, and Other; $8 \%)^{1}$, and non-voting intentions (12\%). Undecided voters were used as the reference group (29\%).

\section{Results}

Table 1 and 2 show how widespread the different forms of climate scepticism are among the British public (Objective 1). Table 1 shows that public belief in climate change has dropped significantly from $91 \%$ in 2005 to $78 \%$ in 2010 , and that the group of individuals who express trend sceptical views, i.e. who do not believe that the world's climate is changing, has grown from 4\% in 2005 to $15 \%$ in 2010 $\left(X^{2}(2)=1.172 . e^{2}, p<0.001\right)$. Table 2 shows that just under one-third $(28 \%)$ are uncertain that climate change is really happening. A clear majority disagree that they are uncertain about the existence of climate change (59\%). In regards to attribution scepticism, people more commonly consider that climate change is caused by a combination of human activity and natural processes $(47 \%)$ or feel it is caused mostly or entirely by human activity (31\%), than consider has mostly or entirely natural causes (18\%). Fifty-seven percent of respondents agree that most scientists agree that humans are causing climate change. A much smaller proportion $(21 \%)$ disagrees with this statement. The sample is split as to whether the seriousness of climate change is exaggerated, with $40 \%$ agreeing and $42 \%$ disagreeing with the statement. Furthermore, respondents express high levels of uncertainty regarding the impacts of climate change. Fully $69 \%$ agree that they are uncertain what the effects of climate change will be, while only $15 \%$ disagree. Overall, impact scepticism appears far more common than both trend and attribution scepticism.

When cross-tabulating the responses to the different climate scepticism questions with the main trend scepticism indicator (see Table 2), it becomes clear that the different types of climate scepticism are closely inter-linked (Objective 2). Respondents' belief in climate change was strongly associated with the other indicator of trend scepticism $\left(X^{2}(2)=2.703 e^{2}, p<0.001\right)$. A clear majority who believe in climate change disagree that they are uncertain that climate change is really happening, while a clear majority of those who do not believe in climate change

\footnotetext{
${ }^{1}$ The numbers of respondents indicating their voting intention for these parties were too small to create separate categories.
} 
agree with the statement. Surprisingly, one out of five who think the world's climate is changing still express some degree of uncertainty about whether it is 'really happening'. A clear majority $(84 \%)$ of respondents who believe in climate change think that it is at least partially caused by human activity; while most of those who do not believe in climate change think that it is at least partially attributable to natural processes $\left(71 \% ; x^{2}(2)=1.339 e^{2}, p<0.001\right)$. Trend scepticism also appears to be associated with perceived scientific consensus regarding the anthropogenic nature of climate change $\left(x^{2}(2)=95.540, p<0.001\right)$, even if more than one out of three trend sceptics still think that most scientists agree that humans are causing climate change. Table 2 also shows strong associations between trend scepticism and impact scepticism $\left(x^{2}(2)=2.188 \mathrm{e}^{2}, p<0.001 ; x^{2}(2)=6.623, p<0.05\right)$, although just under one-third $(31 \%)$ of those who believe in climate change still agree with the statement "The seriousness of climate change is exaggerated". Similarly, Table 2 shows that more than two-thirds of both climate believers and non-believers agree that they are uncertain what the effects of climate change will be. This suggests that that the milder form of impact scepticism is still fairly common even among those who think climate change is happening.

The results presented in Table 3 confirm that the different types of climate scepticism are strongly inter-linked (Objective 2). Correlations between the different indicators of trend, attribution and impact scepticism are medium to large in size (cf. Cohen, 1988), although the correlations with 'uncertainty about the future effects of climate change' are somewhat smaller. Indeed, a scale analysis shows that an internally consistent scale can be created without the latter variable (Cronbach's $\alpha=0.72) .{ }^{2}$ Overall, these results suggest that the general public does not clearly distinguish between the different types of climate scepticism, and that people who are sceptical about one aspect of climate change also tend to be sceptical about other aspects. The 4-item climate scepticism scale is used alongside the trend scepticism indicator reflecting belief in climate change to address the remaining objectives of the study.

\footnotetext{
${ }^{2}$ The trend scepticism indicator reflecting belief in climate change (“...do you personally think the world's climate is changing or not?") was not included in this scepticism scale analysis because it uses a different response scale ('yes', 'no', don't know').
} 
The associations of the main trend scepticism indicator and the constructed climate scepticism scale with other climate-related attitude aspects (Objective 3) are presented in Table 4. The results show that sceptical individuals are less certain and more ambivalent about the climate change than non-sceptical individuals. Nonsceptical individuals express higher levels of attitudinal certainty about climate change, while sceptical individuals express higher levels of attitudinal ambivalence on both the direct and indirect measure. Perhaps not surprisingly, sceptical individual perceive lower risks from climate change than non-sceptical individuals. Slightly conflicting results were found for perceived benefits: whereas it is significantly associated with the climate scepticism scale, its correlation with the trend scepticism indicator is non-significant. Neither sceptical nor non-sceptical groups appear to perceive major benefits associated with climate change. The weakest associations were found for 'affect'. Climate change appears to elicit negative affective responses in both sceptical and non-sceptical groups, suggesting that this may be a source of psychological ambivalence for sceptical individuals. Table 5 shows that correlations with the scepticism scale are generally higher than the ones with the trend scepticism indicator. This is probably due to the lower variance within the binary trend scepticism variable; and shows that, where possible, multiple indicators should be used to reflect the nuance in the degree of climate scepticism.

In order to address Objective 4, to provide a profile of individuals who express sceptical views on climate change, two analyses were conducted regressing the trend scepticism indicator and the constructed climate scepticism scale on the personal values, socio-demographics and voting intention variables. The first column of Table 5 shows the results of a logistic regression analysis using the main trend scepticism indicator as the outcome variable. This shows individuals with environmental and self-transcendence values are more likely to believe the world's climate is changing. Older respondents, in particular those aged 55 and over; social grade $\mathrm{DE}$; and individuals with a conservative or non-voting intention, were significantly more likely to think that the climate is not changing. The second column in Table 5 shows the results of a linear regression analysis with the standardised climate scepticism scale as the outcome variable. Individuals with traditional values expressed higher levels of climate scepticism, while those with environmental and self-transcendence values expressed lower levels of climate scepticism. 
Respondents aged 55 and over; of social grade C1, C2 and DE; and a conservative voting intention expressed higher levels of climate scepticism.

\section{Discussion}

In this paper we have carried out a comprehensive investigation of public scepticism about anthropogenic climate change in Britain using the framework of Rahmstorf (2004). The study explored how widespread trend, attribution and impact sceptical views are among the British public, to what extent they are interlinked, and in what way they are associated with related attitude aspects, such as uncertainty and ambivalence. It further provided a socio-demographic and 'ideological' profile of individuals who express climate sceptical views.

This study suggests that climate scepticism is currently not widespread in Britain. Although belief in the existence of climate change has decreased substantially since a similar survey was conducted in 2005 , still a great majority thinks that the world's climate is changing. Similarly, relatively few people consider climate change to be mostly or entirely caused by natural processes, or perceive scientific uncertainty about the anthropogenic nature of climate change. However, the sample is split with regard to whether the seriousness of climate change has been exaggerated, suggesting that impact scepticism is more common than both trend and attribution scepticism. Despite the absence of widespread trend and attribution scepticism, there still is considerable uncertainty among the British public about the existence and exact impacts of climate change. A sizeable minority expressed uncertainty about whether climate change is really happening; and even among those who think that the world's climate is changing, a majority agrees that they are uncertain what the effects of climate change will be. This is to some extent understandable given the inherent uncertainty in predicting future effects; climate change is perceptually a distant issue, and can only be indirectly judged by the general public through seasonal events and weather (e.g., Weber, 2010). The intangible and abstract nature of climate change may make it difficult for lay publics to engage with the topic and not feel some degree of uncertainty about it (e.g., Kollmuss \& Aygeman, 2002; Weber, 2010). Furthermore, there is legitimate uncertainty about the exact impacts of climate change, as our understanding of how 
climate systems work and interact with human and biological systems is far from complete (Patt \& Dessai, 2005).

As to whether the scepticism model of Rahmstorf (2004) can be used to describe public scepticism about climate change, this study shows that the different forms of climate scepticism are strongly inter-linked. Individuals who are sceptical about one aspect of climate change also tend to be more sceptical about other aspects of climate change, suggesting that the general public does not clearly distinguish between the different types of scepticism. This may mean that uncertainty about one aspect of climate change easily permeates to other areas -a process termed 'uncertainty transfer' by Spence et al. (under review). However, these findings should be nuanced by looking at the distribution of people's views on climate change. Although there are clear associations between the different types of climate scepticism, the study has also shown that the milder form of impact scepticism is far more prevalent than the more extreme trend or attribution scepticism. Even among non-sceptical groups there is still considerable uncertainty about the impacts of climate change. Such uncertainty can hardly be described as an entrenched climate sceptical view. Also, there are a number of trend sceptics who perceive scientific consensus about the anthropogenic nature of climate change, raising the question of what evidence they base their scepticism on. So there appears to be a clear gradation according to the Rahmstorf typology, ranging from a more extreme but relatively rare denial of the existence of climate change to a milder but more common uncertainty about the impacts of climate change. This shows that it is important to use trend, attribution and impact scepticism measures in conjunction to reflect different degrees of climate scepticism.

Attitudinal certainty appears mainly concentrated in non-sceptical groups. Whereas non-sceptical individuals felt more strongly about climate change, sceptical individuals express more mixed feelings and conflicting risk and benefit perceptions. Furthermore, climate change evokes negative affective responses, even among those who expressed high levels of climate scepticism. Here attitudinal ambivalence may results from conflicting cognitive and affective attitude components (Thompson et al., 1995; Lavine et al., 1998). The finding that climate scepticism is associated with attitudinal uncertainty, ambivalence, and conflicting cognitive-affective responses confirms that most climate sceptics may not hold their views very strongly. So, perhaps in contrast to the caricature of a dogmatic sceptic who is 
"waiting to pounce on any scientific uncertainty", climate sceptical publics seem to be less opinionated than non-sceptical publics. Nevertheless, uncertainty about climate change and its potential impacts may still be a major barrier to engagement, as the certain immediate costs of climate change mitigation have to compete with the discounted uncertain future costs of climate adaptation (Weber, 2010). Also, addressing existing uncertainties about different aspects of the climate change debate may be difficult to achieve through conventional risk communication. There is some evidence that, analogously to the asymmetry in trust (see e.g. Poortinga \& Pidgeon, 2005), there is an 'asymmetry in uncertainty', in that it may be easier to instil uncertainty than to communicate certainty, in particular considering the inherent tentativeness of scientific knowledge. According to Michaels and Monforton (2005), a major tactic of opponents of public health and environmental regulations is to "manufacture uncertainty" by questioning the validity of scientific evidence (also see Jacques et al., 2008; Oreskes \& Conway, 2010). Once trust in some of its tenets has been undermined, it may be difficult to regain confidence in climate science again. The durability of distrust amongst sceptical groups is particularly likely given the strong value basis underpinning scepticism (discussed below).

With regard to the socio-demographic profile of climate sceptic publics, the results of this study are surprisingly similar to those of Whitmarsh (in press). Older respondents from lower socio-economic backgrounds and with conservative voting intentions were the most likely to express climate scepticism. Also, people who were politically disengaged (as indicated by a non-voting intention) were generally less likely to believe in the existence of climate change. Previous research conducted in the US and UK suggests that scepticism is most common among men (e.g. Leiserowitz, 2005; Upham et al., 2009). The so-called 'white-male effect' has been widely observed across different environmental and technological hazards (e.g. Flynn et al., 2004; Finucane et al., 2000), suggesting risk perception may be related to individuals' level of decision power or interest in a particular hazard (Satterfield et al., 2004). In other words, those who feel more vulnerable and have less control over an issue tend to express more concern (Bord \& O'Connor, 1997). However, this was not confirmed in the current study. In fact, more 'vulnerable' older respondents from lower socio-economic backgrounds were less likely to believe in possible impacts of anthropogenic climate change. Although the age effects could be explained by possible differences in time horizons in relation to climate change, it is not clear why 
people from a lower socio-economic background are more sceptical about the existence and anthropogenic nature of climate change. A possible explanation is that concerns about climate change and the environment are overshadowed by more immediate financial concerns in the current economic climate (Weber, 2010). In particular people from lower socio-economic backgrounds may feel that they have been hit disproportionately by the late 2008 global economic crisis and subsequent rises in unemployment, with financial insecurities overshadowing concerns about environmental issues. Previous research has shown environmental concerns increase with social class (Bibbings, 2004; Norton \& Leaman, 2004), which supports the idea that once basic material needs have been met 'post-materialistic' values become more important, i.e., that people are more likely to value the protection of the environment (Inglehart, 1990).

The study further confirms that climate scepticism is rooted in people's core values and worldviews, mirroring the findings of Whitmarsh (in press) that political affiliation and environmental values are the strongest correlates of uncertainty about climate change. Using a wider range of personal values from Schwartz' value framework and a nationally representative sample, this study found that selftranscendence, traditional, and environmental values are significantly associated with public views regarding anthropogenic climate change. Climate scepticism was found to be particularly common among individuals who are politically conservative and hold traditional values; while less common among individuals who hold selftranscendence and environmental values. Despite using a different value framework, the results are largely in line with Leiserowitz (2005) who showed those with a conservative hierarchical value orientation have less favourable attitudes to climate change. The apparent political ideological basis of climate-related attitudes may explain why the different forms of scepticism are closely interlinked. The existence of fundamentally different groups - or interpretative communities (cf. Leiserowitz, 2005) - with significantly different outlooks on climate change, implies it is difficult to engage sceptical publics. Simply providing climate change information is unlikely to be successful, as new information is often interpreted in line with people their existing attitudes and worldviews (e.g. Poortinga \& Pidgeon, 2004), in particular where they are based on political ideology and personal values rather than on a critical evaluation of the available evidence (cf. Corner, 2009). Then again, the finding that most sceptics do not hold their views very strongly may offer some hope 
for constructive communication and engagement. Indeed, qualitative work on public understandings of climate change has shown that just because individuals indicate that they do not personally worry about the impacts of climate change does not necessarily mean they think that there is nothing to worry about (Carolan, 2010). The general public may have various psychological reasons for not engaging with climate change, including a general distrust in environmental science, expertise and communication (Burgess et al., 1998; Wynne, 2002), an unwillingness to change their behaviour (Stoll-Kleemann et al., 2001), or despondency brought about by feelings of helplessness and lack of control (Lorenzoni et al., 2007); while others are simply disinterested or bored by the topic (Kerr, 2009). It is therefore important to tailor risk communications to different audiences and take into account the reasons of different publics for expressing doubt or disengagement from climate change, as they are likely to require very different approaches for re-engagement or behavioural change. 


\section{References}

American Psychological Association (2010). Psychology and Global Climate Change. APA.

Anderegg, W.R.L., \& Harold, J. (2009). Climate Science and the dynamics of expert consensusStanford: Schneider Lab at Stanford University and the Center for Conservation Biology.

Anderegg, W.R.L., Prall, J.W., Harold, J., \& Schneider, S.H. (2010a). Expert credibility in climate change. Proceedings of the National Academy of Sciences, 107, 12107-12109.

Anderegg, W.R.L., Prall, J.W., \& Harold, J. (2010b). Reply to O'Neill and Boykoff: Objective classification of climate experts. Proceedings of the National Academy of Sciences, 107(39), E152.

Antilla, L. (2005). Climate of scepticism: U.S. newspaper coverage of the science of climate change. Global Environmental Change, Part A: Human and Policy Dimensions 15(4): 338-352.

Berkhout, F. (2010). Reconstructing boundaries and reason in the climate debate. Global Environmental Change. In Press.

Bibbings, J. (2004). Climate Concern: Attitudes to climate change and windfarms in Wales. Cardiff: Welsh Consumer Council and Friends of the Earth Cymru.

Boholm, A, \& Löfstedt, R. (2004). Facility Siting: Risk, Power and Identity in Land Use Planning. London: Earthscan, 2004.

Bord, R., \& O'Connor, R. (1997). The gender gap in environmental attitudes: The case of perceived vulnerability to risk. Social Science Quarterly, 78, 830-840.

Bord, R.J., O'Connor, R.E., \& Fisher, A. (2000). In what sense does the public need to understand global climate change? Public Understanding of Science, 9, 205218.

Boykoff, M.T., \& Boykoff, J.M. (2004). Balance as bias: global warming and the US prestige press. Global Environmental Change, 14, 125-136.

Breckler, S.J. (1994). A comparison of numerical indices for meassuring attitude ambivalence. Educational and Psychological Measurement, 52(2), 350-365. 
Burgess, J., Harrison, C., \& Filius, P. (1998). Environmental communication and the cultural politics of environmental citizenship. Environment and Planning A, 30, 1445-1460.

Capstick, S., \& Pidgeon (under review). Scepticism within public perspectives on climate change. Public Understanding of Science

Carolan, M. (2010). Sociological ambivalence and climate change. Local Environment, 15(4), 309-321.

Chester, L. (2010). Conceptualising energy security and making explicit its polysemic nature. Energy Policy 38, 887-895.

Cohen, J. (1988). Statistical Power Analysis for the Behavioral Sciences (second ed.). Lawrence Erlbaum Associates.

COI (2008). Attitudes to Climate Change - Amongst Young People - Wave 2. Key Research Findings Prepared for Defra. London: Central Office of Information; http://www.defra.gov.uk/environment/climatechange/uk/individual/attitudes/pdf/ccyouth-tracker-presentation.pdf.

Corner, A. (2010) Do climate change sceptics give scepticism a bad name?, The Guardian. Available at: www.guardian.co.uk/environment/blog/2010/feb/22/climate-change-sceptics. (Accessed 17 February 2011)

Defra. (2002). Survey of public attitudes to quality of life and to the environment: 2001. London: Department for Environment, Food and Rural Affairs.

Defra. (2007). Survey of Public Attitudes and Behaviours toward the Environment: 2007. London: Department for Environment, Food and Rural Affairs.

Defra (2008). Climate Change Act. London: Department for Environment, Food and Rural Affairs. Available at: http://www.decc.gov.uk/en/content/cms/legislation/cc_act_08/cc_act_08.aspx (Accessed 05 October 2010).

De Groot, J. I. M. \& Steg, L. (2008). Value orientations to explain environmental attitudes and beliefs: How to measure egoistic, altruistic and biospheric value orientations. Environment and Behavior, 40, 330-354.

Devine-Wright, P. (2005). Beyond NIMBYism: towards an integrated framework for understanding public perceptions of wind energy. Wind Energy, 8, 125-139. 
Department for Transport (2010). Public Attitudes Towards Climate Change and the Impact of Transport: 2006, 2007, 2008, and 2009 (January 2010 report). London: Department for Transport. Available at: http://www.dft.gov.uk/pgr/statistics/datatablespublications/trsnstatsatt/climatechngea ndtranport1 (Accessed 05 October 2010).

Doran, P.T., \& Zimmerman, M.K. (2009). Examining the scientific consensus on climate change. EOS, Transactions American Geophysical Union, 90, 22-3.

Downing, P., \& Ballantyne, J. (2007). Tipping Point or Turning Point? Social marketing and climate change. London: Ipsos-MORI.

DTI (2003). Energy White Paper: Our Energy Future-Creating a Low Carbon Economy. London: Department for Trade and Industry.

Dunlap, R.E., \& McCright, A.M. (2008a). A Widening gap: Republican and Democratic views on climate change. Environment, 50(5), 26-35.

Dunlap, R.E., McCright, A.M. (2008b). Social movement identity: validating a measure of identification with the environmental movement. Social Science Quarterly, 89, 1045-1065.

Dunlap, R.E., \& McCright, A.M. (2010). Climate change denial: sources, actors and strategies. In C. Lever-Tracy (ed.) Routledge Handbook of Climate Change and Society. Abingdon: Routledge.

Eurobarometer (2009). Europeans attitudes towards climate change (Special Eurobarometer 332). Europe: European Commission. Available at: http://ec.europa.eu/public_opinion/archives/ebs/ebs_322_en.pdf (Accessed 05 October 2010).

Finucane, M., Slovic, P., Mertz, C., Flynn, J., \& Satterfield, T. (2000). Gender, race, and perceived risk: The "white male" effect. Health Risk \& Society, 2, 159-172.

Flynn, J., Slovic, P., \& Mertz, C. (1994). Gender, race, and perception of environmental health risks. Risk Analysis, 14, 1101-1108

Gifford, R., Scannell, L., Kormos, C., Smolova, L., Biel, A., Boncu, S., et al. (2009). Temporal pessimism and spatial optimism in environmental assessments: An 18-nation study. Journal of Environmental Psychology, 29, 1-12.

Hargreaves, I., Lewis, J. and Speers, T. (2003) Towards a better map: Science, the public and the media. London: Economic and Social Research Council. Hulme, M., (2009). Why we Disagree about Climate Change? Cambridge: Cambridge University Press. 
Inglehart, R. (1990). Culture Shift in Advanced Industrial Society. Princeton, $\mathrm{NJ}$ : Princeton University Press.

Jacques, P., Dunlap, R., \& Freeman, M. (2008). The organization of denial: conservative think tanks and environmental skepticism. Environmental Politics, 17, 349-385.

Joireman, J., Truelove, H. B., \& Duell, B. (2010). Effect of outdoor temperature, heat primes and anchoring on belief in global warming. Journal of Environmental Psychology, 30(4), 358-367.

Jonas, K., Brömer, P., \& Diehl, M. (2000). Attitudinal ambivalence. European Review of Social Psychology, 11, 35-74.

Kerr, R.A. (2009).Climate change: amid worrisome signs of warming, 'climate fatigue' sets in. Science, 326(5955), 926-928.

Krosnick, J. (2010). The Climate Majority. The New York Times. Available at http://www.nytimes.com/2010/06/09/opinion/09krosnick.html?_r=1\&ref=opinion\&pag ewanted=all. (Accessed 05 October 2010).

Lavine, H., Thomsen, C.J., Zanna, M.P., \& Borgida, E. (1998). On the primacy of affect in the determination of attitudes and behavior: the moderating role of affective-cognitive ambivalence. Journal of Experimental and Social Psychology, 34, 398-421.

Leiserowitz, A. (2005). American risk perceptions: Is climate change dangerous?. Risk Analysis, 25, 1433-1442.

Leiserowitz, A., Maibach, E., \& Roser-Renouf, C. (2010a). Climate change in the American mind: Americans' global warming beliefs and attitudes in January 2010. Yale University and George Mason University. New Have: CT. Yale Project on Climate Change.

Available at: http://environment.yale.edu/uploads/AmericansGlobalWarmingBeliefs2010.pdf (Accessed 05 October 2010).

Leiserowitz, A., Maibach, E., Roser-Renouf, C., \& Smith, N. (2010) Climate change in the American Mind: Americans' global warming beliefs and attitudes in June 2010. Yale University and George Mason University. New Haven, CT: Yale Project on Climate Change Communication. Available at: http://environment.yale.edu/climate/files/ClimateBeliefsJune2010.pdf (Accessed 05 October 2010). 
Lindeman, M. \& Verkasalo, M. (2005). Measuring values with the Short Schwartz's Values Survey. Journal of Personality Assessment, 85(2) 170-178.

Lorenzoni, I., Doria, M., Leiserowitz, A., Poortinga, W., \& Pidgeon, N.F. (2006). Cross-national comparisons of image associations with 'global warming' and 'climate change' among laypeople in the United States of America and Great Britain. Journal of Risk Research, 9(3), 265-281.

Lorenzoni, I., Nicholson-Cole, S., \& Whitmarsh, L. (2007). Barriers perceived to engaging with climate change among the UK public and their policy implications. Global Environmental Change, 17, 445-459.

Lorenzoni,I., \& Pidgeon,N. (2006). Public views on climate change: Europe and USA perspectives. Climatic Change, 77, 73-95

Lowe, T., Brown, K., Dessai, S., de França Doria, M., Haynes, K., \& Vincent, K. (2006). Does tomorrow ever come? Disaster narrative and public perceptions of climate change. Public Understanding of Science, 15(4), 435-457.

McCright, A.M. (2007). Dealing with climate change contrarian. In S.C. Moser \& L. Dilling (Eds.) Creating a Climate for Change: Communicating Climate Change and Facilitating Social Change L Cambridge: Cambridge University Press, pp 200212.

Michaels, D., \& Monforton, C. (2005). Manufacturing uncertainty: Contested science and the protection of the public's health and environment. Public Health Matters, 95(1), s39-s48

Nature editorial (2010). Climate of fear. Nature, 464, 141-141.

Nehrlich, B. (in press). Scientific Certainty, Consensus and Credibility: How 'climategate' reframed climate science and endangers climate change communication.

Norton, A. \& Leaman, J. (2004). The Day After Tomorrow: Public opinion on climate change. London: MORI Social Research Institute.

O'Neill, S., \& Boykoff, M.T. (2010). Climate denier, skeptic, or contrarian? Proceedings of the National Academy of Sciences, 107(39), E151.

O'Neill, S., \& Nicholson-Cole, S. (2009). "Fear Won't Do It": promoting positive engagement with climate change through visual and iconic representations. Science Communication 30, 355-379.

Oreskes, N., \& Conway, E. (2010). Merchants of Doubt. London: Bloomsbury Press. 
Patt, A., \& Dessai, S. (2005). Communicating uncertainty: lessons learned and suggestions for climate change assessment. Geoscience, 337, 425-441.

Petty, R.E., \& Krosnick, J.A. (1995). Attitude Strength: Antecedents and Consequences. Mahwah: Lawrence Erlbaum Associates.

Pidgeon, N.F., \& Butler, C. (2009). Risk analysis and climate change. Environmental Politics, 18(5), 670-688.

Pidgeon, N.F., Lorenzoni, I., \& Poortinga, W. (2008). Climate change or nuclear power - no thanks! A quantitative study of public perceptions and risk framing in Britain. Global Environmental Change, 18(1), 69-85

Poortinga, W., \& Pidgeon, N.F. (2004). Trust, the asymmetry principle, and the role of prior beliefs. Risk Analysis, 24(6), 1475-1486.

Poortinga, W., \& Pidgeon, N.F. (2006). Exploring the structure of attitudes toward genetically modified food. Risk Analysis, 26(6), 1-13.

Poortinga W., Pidgeon, N.F., \& Lorenzoni, I. (2006). Public Perceptions of Nuclear Power, Climate Change and Energy Options in Britain: Summary Findings of a Survey Conducted during October and November 2005. Technical Report (Understanding Risk Working Paper 06-02). Norwich: Centre for Environmental Risk.

Poortinga, W., Steg, L. \& Vlek, C. (2004). Values, Environmental Concern and Environmental Behaviour: A study into household energy use. Environment \& Behaviour 36, 70-93.

Rahmstorf, S. (2004). The climate sceptics. Potsdam: Potsdam Institute for Climate Impact Research. Available at:

http://www.pik-potsdam.de/ stefan/Publications/Other/rahmstorf_climate_sceptics_2004.pdf (Accessed 05 October 2010).

Rayner, S., \& Malone, E.L. (1997). Zen and the art of climate maintenance. Nature, 390, 332-334.

Satterfield, T., Mertz, C., \& Slovic, P. (2004). Discrimination, vulnerability, and justice in the face of risk. Risk Analysis, 24, 115-129.

SDC (2008) Turning the Tide. London: Sustainable Development Commission.

Shackley, S., McLachlan, C., \& Gough, C. (2005). The public perception of carbon dioxide capture and storage in the UK: results from focus groups and a survey. Climate Policy, 4(4), 377-398. 
Slimak, M.W., \& Dietz, T., (2006). Personal values, beliefs, and ecological risk perception. Risk Analysis, 26(6) 1689-1705.

Spence, A., \& Pidgeon, N.F. (2009). Psychology, climate change and sustainable behaviour. Environment, 51(6), 8-18.

Spence, A., Poortinga, W., Pidgeon, N. \& Lorenzoni, I. (2010a). Public perceptions of energy choices: The influence of beliefs about climate change and the environment. Environment and Energy, 21(5), 384-407.

Spence, A., Venables, D., Pidgeon, N., Poortinga, W. and Demski, C. (2010b). Public Perceptions of Climate Change and Energy Futures in Britain: Summary Findings of a Survey Conducted in January-March 2010. Technical Report (Understanding Risk Working Paper 10-01). Cardiff: School of Psychology

Spence, A., Poortinga, W., Pidgeon, N.F. (under review). The Psychological Distance of Climate Change. Submitted.

Stern, P. C. (2000). Towards a coherent theory of environmentally significant behavior. Journal of Social Issues 56(3), 407-424.

Stoll-Kleemann, S., O'Riordan, T., \& Jaeger. C.C. (2001). The psychology of denial concerning climate mitigation measures: Evidence from Swiss focus groups. Global Environmental Change, 11, 107-118.

Tabachnick, B. G., \& Fidell, L. S. (2005). Using multivariate statistics. Fifth edition. London: Allyn \& Bacon.

Thompson, M.M., Zanna, M.P., \& Griffin, D.W. (1995). Let's not be indifferent about (attitudinal) ambivalence. In R. E. Petty \& J. A. Krosnick (Eds.), Attitude strength: antecedents and consequences. Hillsdale: Erlbaum.

Toke, D. (2005). Explaining wind power planning outcomes: some findings from a study in England and Wales. Energy Policy, 33, 1527-1539.

Upham, P., Whitmarsh, L., Poortinga,W., Purdam, K., Darnton, A., McLachlan, C. \& Devine-Wright, P. (2009) Public Attitudes to Environmental Change: a selective review of theory and practice. A research synthesis for the Living with Environmental Change Programme, Research Councils UK.

Upreti, B. (2004). Conflict over biomass energy development in the United Kingdom: some observations and lessons from England and Wales. Energy Politics, 32, 785-800.

Weber, E.U. (2010). What shapes perceptions of climate change? Wiley Interdisciplinary Reviews: Climate Change, 1(3), 332-342. 
Whitmarsh, L. (2005). A study of public understanding of and response to climate change in the South of England. Unpublished doctoral thesis. Bath: Department of Psychology, University of Bath.

Whitmarsh, L. (2009). What's in a name? Commonalities and differences in public understanding of "climate change" and "global warming". Public Understanding of Science, 18, 401-420.

Whitmarsh, L. (in press). Scepticism and uncertainty about climate change: dimensions, determinants and change over time. Global Environmental Change

Whitmarsh, L. \& O'Neill, S. (2010). Green identity, green living? The role of pro-environmental self-identity in determining consistency across diverse proenvironmental behaviours. Journal of Environmental Psychology, 30(3), 305-314.

Whitmarsh, L., Seyfang, G., \& O'Neill, S. (2011). Public engagement with carbon and climate change: To what extent is the public 'carbon capable'? Global Environmental Change, 21, 56-65

Wynne, B. (2002). Risk and environment as legitimatory discourses of technology: reflexivity inside out? Current Sociology, 50(3), 459-477. 
Table 1. Responses to the question" As far as you know, do you personally think the world's climate is changing or not?" in 2005 and 2010 (\%)

\begin{tabular}{|l|c|c|}
\hline & $\begin{array}{c}2005^{\mathrm{a}} \\
(\mathrm{n}=1,491)\end{array}$ & $\begin{array}{c}2010 \\
(\mathrm{n}=1,822)\end{array}$ \\
\hline Yes & 91 & 78 \\
\hline No & 4 & 15 \\
\hline Don't Know & 5 & 6 \\
\hline
\end{tabular}

Note (a) Source: 2005 UEA/MORI Energy Survey (see Poortinga et al., 2006). 
Table 2. Cross tabulations of trend, attribution, and impact scepticism indicators (\%)

\begin{tabular}{|c|c|c|c|c|}
\hline & & Trend S & ticism & \\
\hline & & $\begin{array}{r}\text { Do you pe } \\
\text { the world } \\
\text { changi }\end{array}$ & $\begin{array}{l}\text { nally think } \\
\text { limate is } \\
\text { or not? }\end{array}$ & \\
\hline & & $\begin{array}{c}\text { Yes } \\
(n=1,427)\end{array}$ & $\begin{array}{c}\text { No } \\
(n=279)\end{array}$ & $\begin{array}{c}\text { Overall } \\
(n=1,822)\end{array}$ \\
\hline Trend Scepticism & & & & \\
\hline I am uncertain that climate & Tend to/strongly agree & 20 & 63 & 28 \\
\hline change is really happening & Neither agree/disagree & 9 & 16 & 12 \\
\hline & Tend to/strongly disagree & 70 & 19 & 59 \\
\hline Attribution Scepticism & & & & \\
\hline Causes of climate change & $\begin{array}{l}\text { Mainly/entirely caused by } \\
\text { natural processes } \\
\text { partly caused by natural }\end{array}$ & 14 & 37 & 18 \\
\hline & $\begin{array}{l}\text { processes and partly } \\
\text { caused by human activity }\end{array}$ & 48 & 34 & 46 \\
\hline & $\begin{array}{l}\text { Mainly/entirely caused by } \\
\text { human activity processes }\end{array}$ & 36 & 10 & 31 \\
\hline Most scientists agree that & Tend to/strongly agree & 63 & 34 & 57 \\
\hline humans are causing climate & Neither agree/disagree & 16 & 18 & 17 \\
\hline crange & Tend to/strongly disagree & 17 & 40 & 21 \\
\hline Impact Scepticism & & & & \\
\hline The seriousness of climate & Tend to/strongly agree & 31 & 76 & 40 \\
\hline change is exaggerated & Neither agree/disagree & 15 & 11 & 15 \\
\hline & Tend to/strongly disagree & 52 & 10 & 42 \\
\hline It is uncertain what the & Tend to/strongly agree & 69 & 71 & 69 \\
\hline effects of climate change will & Neither agree/disagree & 12 & 11 & 12 \\
\hline be & Tend to/strongly disagree & 18 & 11 & 15 \\
\hline
\end{tabular}

Note: figures in the table may not add up to $100 \%$ due to missing values and rounding 
Table 3. Correlations between trend, attribution and impact scepticism indicators

\begin{tabular}{|c|c|c|c|c|c|c|}
\hline & 1 & 2 & 3 & 4 & 5 & 6 \\
\hline \multicolumn{7}{|l|}{ Trend Scepticism } \\
\hline $\begin{array}{l}1 \text { Do you personally think the world's } \\
\text { climate is changing or not? }\end{array}$ & 1.00 & & & & & \\
\hline $\begin{array}{l}2 \text { I am uncertain that climate change is } \\
\text { really happening }\end{array}$ & $0.39^{* * *}$ & 1.00 & & & & \\
\hline \multicolumn{7}{|l|}{ Attribution Scepticism } \\
\hline 3 Causes of climate change & $0.26^{* * *}$ & $0.29^{* * *}$ & 1.00 & & & \\
\hline $\begin{array}{l}4 \text { Most scientists agree that humans are } \\
\text { causing climate change }\end{array}$ & $0.24^{* * *}$ & $0.28^{* * *}$ & $0.48^{* * *}$ & 1.00 & & \\
\hline \multicolumn{7}{|l|}{ Impact Scepticism } \\
\hline $\begin{array}{l}5 \text { The seriousness of climate change is } \\
\text { exaggerated }\end{array}$ & $0.39^{* * *}$ & $0.47^{* * *}$ & $0.45^{* * *}$ & $0.38^{* * *}$ & 1.00 & \\
\hline $\begin{array}{l}6 \text { It is uncertain what the effects of } \\
\text { climate change will be }\end{array}$ & $0.07^{*}$ & $0.17^{* * *}$ & $0.18^{* * *}$ & $0.09^{* * *}$ & $0.19^{* * *}$ & 1.00 \\
\hline
\end{tabular}

Note ${ }^{*} p<0.05,{ }^{* * *} p<0.001$. 
Table 4. Associations between climate scepticism and related attitude aspects

\begin{tabular}{|l|c|c|}
\hline & Trend Scepticism & Climate Scepticism \\
\hline Attitude Certainty & $-0.18^{* * *}$ & $-0.38^{* * *}$ \\
Attitudinal Ambivalence & $0.06^{*}$ & $0.31^{* * *}$ \\
Ambivalence Index & $0.08^{* *}$ & $0.29^{* *}$ \\
-Perceived Risks & $-0.39^{* * *}$ & $-0.53^{* * *}$ \\
-Perceived Benefits & $0.04^{\text {n.s. }}$ & $0.26^{* * *}$ \\
Affect & $0.03^{\text {n.s. }}$ & $0.17^{* * *}$ \\
\hline
\end{tabular}

Note ${ }^{*} p<0.05,{ }^{* *} p<0.01,{ }^{* * *} p<0.001$, n.s.=non-significant. 
Table 5. Logistic regression ("Trend Scepticism") and linear regression ("Climate Scepticism" scale) analysis of climate scepticism

\begin{tabular}{|c|c|c|c|c|c|c|}
\hline & \multicolumn{3}{|c|}{$\begin{array}{l}\text { Trend Scepticism }{ }^{\text {a }} \\
\text { Do you personally think } \\
\text { the world's climate is } \\
\text { changing or not } \\
\text { (no versus yes) }\end{array}$} & \multicolumn{3}{|c|}{ Climate Scepticism $^{\text {b }}$} \\
\hline & OR & $95 \% \mathrm{Cl}$ & $\mathbf{p}$ & B & SE & $\mathbf{p}$ \\
\hline \multicolumn{7}{|l|}{ Personal Values } \\
\hline Self-Enhancement & 1.15 & $0.97-1.36$ & n.s. & 0.03 & 0.03 & n.s. \\
\hline Openness to Change & 1.20 & $0.99-1.45$ & n.s. & 0.05 & 0.03 & n.s. \\
\hline Self-Transcendence & 0.78 & $0.64-0.94$ & $* *$ & -0.10 & 0.03 & ** \\
\hline Traditional Values & 1.14 & $0.95-1.36$ & n.s. & 0.13 & 0.03 & $* * *$ \\
\hline Environmental Values & 0.69 & $0.58-0.82$ & $* * *$ & -0.26 & 0.03 & $* * *$ \\
\hline \multicolumn{7}{|l|}{ Gender (female) } \\
\hline Male & 1.19 & $0.89-1.61$ & n.s. & -0.02 & 0.05 & n.s. \\
\hline \multicolumn{7}{|l|}{ Age (17-24) } \\
\hline $25-34$ & 0.93 & $0.50-1.73$ & n.s. & -0.07 & 0.09 & n.s. \\
\hline $35-44$ & 1.94 & $1.11-3.38$ & * & 0.03 & 0.09 & n.s. \\
\hline $45-54$ & 1.54 & $0.86-2.78$ & n.s. & 0.13 & 0.09 & n.s. \\
\hline $55-64$ & 2.79 & $1.56-4.99$ & $* * *$ & 0.24 & 0.10 & * \\
\hline 65 and over & 2.66 & $1.51-4.67$ & $* * *$ & 0.33 & 0.09 & $* * *$ \\
\hline \multicolumn{7}{|l|}{ Social Grade (AB) } \\
\hline $\mathrm{C} 1$ & 0.97 & $0.65-1.46$ & n.s. & 0.15 & 0.07 & * \\
\hline $\mathrm{C} 2$ & 1.50 & $0.98-2.30$ & n.s. & 0.18 & 0.07 & * \\
\hline $\mathrm{DE}$ & 1.56 & $1.01-2.41$ & * & 0.18 & 0.08 & * \\
\hline \multicolumn{7}{|c|}{ Voting Intention (undecided) } \\
\hline Conservative & 1.94 & $1.28-2.94$ & $* *$ & 0.19 & 0.07 & ** \\
\hline Labour & 1.37 & $0.88-2.13$ & n.s. & -0.13 & 0.07 & n.s. \\
\hline Liberal Democrats & 1.19 & $0.65-2.17$ & n.s. & -0.06 & 0.09 & n.s. \\
\hline Other & 1.26 & $0.70-2.27$ & n.s. & 0.01 & 0.10 & n.s. \\
\hline Would not Vote & 1.98 & $1.22-3.21$ & ** & -0.00 & 0.09 & n.s. \\
\hline
\end{tabular}

Note ${ }^{*} p<0.05,{ }^{* *} p<0.01,{ }^{* * *} p<0.001$, n.s.=non-significant; (a) odds ratios (OR) and $95 \%$ confidence intervals $(95 \% \mathrm{Cl})$; (b) unstandardised regression coefficients (B) and standard errors (SE). 